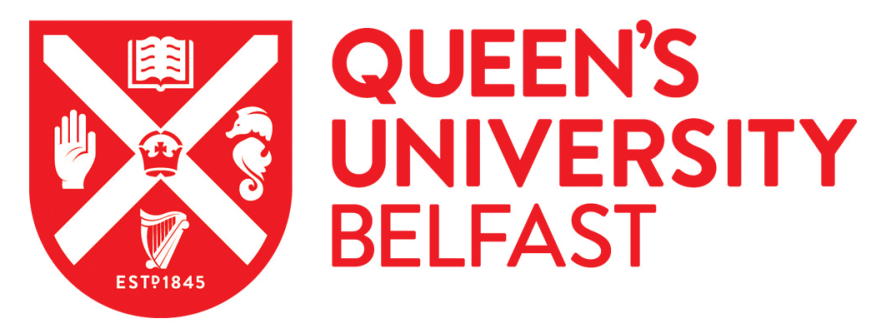

\title{
The Old English Life of Saint Mary of Egypt and London, British Library, Cotton Julius E.vii: A Textual Study
}

Magennis, H. (2021). The Old English Life of Saint Mary of Egypt and London, British Library, Cotton Julius E.vii: A Textual Study. Anglia, 139(2). https://doi.org/10.1515/ang-2021-0025

\section{Published in:}

Anglia

Document Version:

Publisher's PDF, also known as Version of record

Queen's University Belfast - Research Portal:

Link to publication record in Queen's University Belfast Research Portal

\section{Publisher rights}

Copyright 2021 the authors.

This is an open access article published under a Creative Commons Attribution License (https://creativecommons.org/licenses/by/4.0/), which permits unrestricted use, distribution and reproduction in any medium, provided the author and source are cited.

\section{General rights}

Copyright for the publications made accessible via the Queen's University Belfast Research Portal is retained by the author(s) and / or other copyright owners and it is a condition of accessing these publications that users recognise and abide by the legal requirements associated with these rights.

Take down policy

The Research Portal is Queen's institutional repository that provides access to Queen's research output. Every effort has been made to ensure that content in the Research Portal does not infringe any person's rights, or applicable UK laws. If you discover content in the Research Portal that you believe breaches copyright or violates any law, please contact openaccess@qub.ac.uk. 
Hugh Magennis*

\section{The Old English Life of Saint Mary of Egypt and London, British Library, Cotton Julius E.vii: A Textual Study}

https://doi.org/10.1515/ang-2021-0025

Abstract: This article highlights the textual distinctiveness of the Old English Life of Saint Mary of Egypt in its manuscript context in British Library, Cotton Julius E.vii. The Cotton Julius version of the Life is distinctive in the sheer number of scribal errors it contains but also in the purposeful changes to the original translation evident in it. Consideration of scribal performance across the manuscript and comparison with texts of Saint Mary of Egypt extant elsewhere lead to the conclusion that the purposeful changes in the Cotton Julius witness have probably been inherited from an exemplar, while the number of errors is likely due to the pressure under which the scribe was working in adding this text at a late stage of the manuscript's composition. Despite its distinctive features, there is no evidence to contradict the recently argued contention that this version of Saint Mary of Egypt, along with the second half of the immediately preceding item in the manuscript, the Legend of the Seven Sleepers, was copied by the main scribe of Cotton Julius rather than being delegated to a colleague: although Seven Sleepers also seems to have been copied under pressure, Saint Mary of Egypt stands apart from it in broadly the same ways as it does from the rest of the manuscript.

Key terms: Old English language and literature, hagiography, Late West Saxon, manuscript studies, scribal practice, textual transmission

*Corresponding author: Hugh Magennis, Queen's University Belfast

E-Mail: H.Magennis@qub.ac.uk

Ә Open Access. $\odot 2021$ Hugh Magennis, published by De Gruyter. (c) BY the Creative Commons Attribution 4.0 Public International License. 


\section{Introduction}

The text of the anonymous Life of Saint Mary of Egypt ${ }^{1}$ in London, British Library, Cotton Julius E.vii (W) is our principal witness to the Old English translation; substantial fragments of the Life survive in two other manuscripts, London, British Library, Cotton Otho B.x (O) and Gloucester, Cathedral Library, 35 (G), but nearly half of it is extant in $\mathrm{W}$ alone. ${ }^{2} \mathrm{~W}$, which dates from the very early eleventh century, is celebrated as the manuscript that uniquely contains Ælfric's Lives of Saints as an integrated collection, as well as Saint Mary of Egypt and three other anonymous items, Saint Euphrosyne, Saint Eustace and Seven Sleepers. ${ }^{3}$ O, a compendium mostly of saints' lives, dates from the first half of the eleventh century, while G, of which very little survives apart from the Saint Mary of Egypt fragments, comes from the mid-eleventh century. There is one passage of 132 words (out of a total of just over 8,000) that is found in all three manuscripts. Appendix A (below, p. 397) tabulates overlaps among the three texts.

Although W is our principal witness to Saint Mary of Egypt, it is a highly fallible guide to the text produced by the original translator, as the present article brings out. ${ }^{4}$ Indeed, the Life has such a quantity of textual errors and other changes that it is surely the most imperfect copy of a saint's life in the entire Old English prose corpus. ${ }^{5}$

1 The Life is edited and translated in Magennis (2002); primary references below (by line number) are to this edition; also ed. and trans. Skeat (1881-1900: II, 2-53); and ed. and trans. Kramer, Magennis and Norris (2020: 379-439) (D, referred to below by section number).

2 For the O text, see Cantara (2011); for G, see Earle (1861: 99-116).

3 References below (by line number) to Ælfric's lives in Lives of Saints and to Euphrosyne, Eustace and Seven Sleepers are to Skeat (1881-1900), though for Seven Sleepers primary references are to Magennis (1994). The following Ælfric lives are referred to in this article: Eugenia (Skeat I, 24-51), Basil (Skeat I, 50-91), Julian and Basilissa (Skeat I, 90-115); for Seven Sleepers, Eustace and Euphrosyne, respectively, see Skeat (I, 488-541), Skeat (II, 190-219) and Skeat (II, 334-355); for the Ælfrician lives, references (by line number) are also given to Clayton and Mullins (2019= CM) (Eugenia I, 44-73, Basil I, 76-121, Julian and Basilissa I, 124-153), but only where the lineation departs from that of Skeat; for Euphrosyne, Eustace and Seven Sleepers, references (by section number) are also given to Kramer, Magennis and Norris (2020) (Euphrosyne 28-53, Eustace 56-91, Seven Sleepers 588-651). 4 The Latin original is edited and translated in Magennis (2002: 74-91; referred to below by line number).

5 A rival candidate for this accolade might be the Cotton Vespasian D.xxi Saint Guthlac, which, like Saint Mary of Egypt, makes purposeful changes to an inherited text with many non-West Saxon features, having been written originally in Anglian. Saint Guthlac is preserved in a later manuscript than the Mary of Egypt ones (s. $\mathrm{xi}^{2}$ ), with some transitional linguistic features as well as Late West Saxon forms; even so, it has far fewer errors and omissions than Mary of Egypt; on the Guthlac translation, see Roberts (1986). 


\section{Cotton Julius E.vii: Copying and Copyists}

It is relevant to give a short contextualizing account of scribal activity in W before focusing specifically on textual features of the Life of Saint Mary of Egypt. As set out in the table in Appendix B (below, p. 398), most of the manuscript was written by one scribe, 'Scribe A', who copied all the material up to the Legend of the Seven Sleepers, the item occurring immediately before Saint Mary of Egypt. At the beginning of Seven Sleepers a second scribe took over, 'Scribe B', copying just over half of Seven Sleepers, at which point there was another change of hand (at the beginning of a new quire) to that of the scribe who copied the rest of Seven Sleepers and all of Saint Mary of Egypt. It is clear that Saint Mary of Egypt was inserted in the manuscript only as a late addition, with improvised arrangements needed for its inclusion. Saint Mary of Egypt is not listed in the manuscript's table of contents and is out of position in a collection organized on a calendrical basis; and a page and a half remain blank at the end of the text. ${ }^{6}$

After Saint Mary of Egypt, Scribe A resumed in a style identical to that of the first part of the manuscript, thus writing the lion's share of the whole. Scribe A also later went over many of the texts in W, including Saint Mary of Egypt, making occasional corrections, though leaving most errors unemended. ${ }^{7}$

The scribe of the second part of Seven Sleepers and Saint Mary of Egypt has been referred to as 'Scribe C', but N. R. Ker (1957: 210) suggested that Scribe C may actually be Scribe A, though writing here in a more cramped, compressed style, and recently Michèle Bussières (2007) has provided compelling graphological and orthographic evidence that this is indeed the case. ${ }^{8}$ Saint Mary of Egypt and the second part of Seven Sleepers are also written in the same generally regular form of Late West Saxon as the Scribe A texts. This form of Late West Saxon, referred to in scholarship as 'Standard Old English', was widely in use in late Anglo-Saxon England. ${ }^{9}$ It had distinct preferences in spelling and grammar, but many scribes, including Scribe B (and also $\mathrm{G}$ and $\mathrm{O}),{ }^{10}$ were less inconsistent than Scribe A in following its norms.

6 On the late inclusion of Mary of Egypt in W and the steps in the manuscript's construction, see Scragg (1996: 217-218).

7 A second corrector, working slightly later than the first, made emendations to many of the items in W (but not Saint Mary of Egypt), mostly regularizing spelling and phonology but occasionally also intervening on grounds of sense. This corrector is referred to below as the 'point' corrector, as the corrections are often accompanied by a single or double point sign written below the line; on this corrector, see Needham (1958).

8 On scribal activity across the manuscript, see Bussières (2004).

9 On Standard Old English, see Gneuss (1972), Gretsch (2003).

10 On differences between Scribe B and the rest of the manuscript, see Section 8, below, pp. 393395. 
Although approximating well to Standard Old English, the language of manuscript W displays what Mechthild Gretsch refers to as "some scribal peculiarities" (2003: 46). In particular, Gretsch mentions widespread confusion between long and short $æ$ and $e$, between long and short $i$ and $y$ and between $a$, $o$ and $u$ in inflexional endings and their merger with original $e$ (2003: 46-48) ${ }^{11}$ It is notable that these peculiarities are represented not only in the work of Scribe A but also in that of Scribe B and 'Scribe C' ${ }^{12}$ Another feature present in all three stints is occasional confusion between the definite article/demonstrative pone and ponne 'then, when'. ${ }^{13}$ A spelling trait shared by Scribe A and 'Scribe C' but not paralleled in Scribe B is $-n c g$ for $-n g$ after a front vowel, most commonly but by no means only in pincg 'thing' ${ }^{14}$

Out of practical necessity, modern editions of Saint Mary of Egypt are based on $\mathrm{W}$, despite its imperfections, supported where available by the two other variants. $\mathrm{G}$ and $\mathrm{O}$ also have evident omissions ${ }^{15}$ and departures from the original text of the translation, ${ }^{16}$ but to nothing like the extent apparent in $\mathrm{W}$. The latter text

11 Such features are common in manuscripts from the tenth century onwards but Gretsch observes that the first two of them seem to be "rather more prominent in Julius E vii than in other (near-)contemporary manuscripts" (2003: 48). See also Bussières (2007).

12 Mary of Egypt has numerous instances of levelled inflections but, unlike other texts in W, has no dative plurals in -an or -on.

13 The relevant Scribe $B$ and 'C' readings are pone pisne sealmsang 'then this psalm' (Mary of Egypt [Scribe C], 148, Skeat 120, D 19), Pone swa oft swa 'Then as often as' (Sleepers [Scribe B], 117, Skeat 131, D 19); instances in Scribe A texts are ponne hyred 'the community' (Eugenia 127), ponne cristenan 'the Christian' (Eugenia 298, CM 299), Jonne mæran biscop 'the glorious bishop' (Eugenia 305, CM 306), ponne bisceop philippum 'the bishop Philip' (Eugenia 313, CM 314), pone hi hwæs bædon 'when they prayed for anything' (Euphrosyne 213, D 34).

14 'C' examples in Seven Sleepers include pincg (7 times), cypincge 'market', næmnincg 'name' (548, Skeat 598, D 86, etc.; 592, Skeat 647, D 95; 628, Skeat 684, D 98); in Mary of Egypt, pincg (16 times), mæncgan 'mingle', lencgu 'length' (49, Skeat 40, D 7, etc.; 468, Skeat 411, D 54; 606, Skeat 522, D 69); examples elsewhere in W include andfæncge 'acceptable', celincge 'coolness', clysincge 'enclosure' (Julian and Basilissa 280, CM 281; 340, CM 341; 343, CM 344), pincg (Euphrosyne 221, D 35).

15 To give two examples from $\mathrm{O}$ (out of half a dozen instances), at 101 (Skeat 82, D 13) O omits gife 'gift/grace', reading $b[:::]$ (presumably $p æ r e$ ) with no accompanying noun, though one is required, where W has pære gife 'the gift/grace' (translating Latin gratia, 110); at 409 (Skeat 363-364, D 48), where W reads Eala pu gastlice modor 'O spiritual mother', O omits modor (which translates mater, 423). Examples of accidental omission in G (I count eight instances altogether) include and byfigende 'and trembling' (286, Skeat 232, D 33), corresponding to Latin et tremens (289), and Godes (491, Skeat 430, D 57), corresponding to Latin Dei (494).

16 Examples of miscopying in O include (out of six instances) lufode 'loved' for W leofode 'lived' (387, Skeat 345, D 46) (reflecting Latin viventi 'living', 403); middan for W (also G) middaneardes 'world' (560, Skeat 487, D 65) (translating orbis, 552); gewæg for W se wæg 'the way' (568, Skeat 493, 
abounds in changed readings: words, phrases, and grammatical constructions have deliberately been altered; embellishing details have occasionally been added; and, most noticeably, the text is littered with copying errors, accidental omissions, and mistaken readings. The W Saint Mary of Egypt thus presents a curious combination of active editing and scribal inattentiveness, underlain by informed observation of the linguistic standards of Standard Old English.

I argue that deliberate changes to the text have probably been passed on from an exemplar rather than being contributed by the W copyist. Some of the textual deficiencies in $\mathrm{W}$ may also have been inherited from an exemplar but, if so, the $\mathrm{W}$ scribe must have read the exemplar extremely uncritically, and it is clear that some such deficiencies are directly attributable to the $\mathrm{W}$ scribe.

\section{Scribal Slips and Omissions in the Cotton Julius E.vii Saint Mary of Egypt}

As shown below, the idiosyncracy of the W text of Saint Mary of Egypt is particularly confirmed by comparison with $\mathrm{G}$ and $\mathrm{O}$, but it is also evident in the parts of the text extant only in $\mathrm{W}$, in which there are a large number of departures from what the scribe would have seen in the exemplar in front of him or her (unless the W scribe heedlessly copied existing mistakes).

\subsection{Textual Duplication and Words Copied in Error}

Among the egregious errors in $\mathrm{W}$ is a passage (792-805, Skeat 671-682, D 90-92) written twice, with a significant number of variations between the two iterations. Most strikingly, berende 'bearing' (793, Skeat 672, D 90) (translating Latin portans, 746) is miscopied in the second iteration as ne bere 'do not bear', which makes no sense in the context; hi geseonde 'seeing her' (800, Skeat 678, D 91) (Latin videns eam, 753-754) is miscopied in the second iteration as heo to geseonne 'she to see', which again makes no sense; he (794, Skeat 673, D 90) is omitted in the second iteration, leaving its clause subjectless; $h w æ r$ 'where' (799, Skeat 677, D 91) is changed to $p æ r$ 'there' in the second iteration, though the sense requires $h w æ r$.

D 66). Examples of miscopying in $\mathrm{G}$ are few and far between: hire is written twice by mistake in $p e$ hire ær Zosim hire towearp 'which Zosimus has previously thrown to her' (945, Skeat 792-793, D 107); it has the masculine sylfne 'self' (537, Skeat 469, D 62) where W has the correct feminine form sylfe; and siðfæc appears for siðfæt 'journey’ (571, Skeat 496, D 66) (Latin iter, 561). 
As well as these four significant discrepancies, ten other minor contrasts between the two versions are evident, in a passage of only fourteen lines. These comprise orthographic changes: heonone/heonon 'from here' (792, Skeat 672, D 90), cweðеnde/cwæðеnde 'saying' (795, Skeat 674, D 90), sceall/sceal 'shall' (796, Skeat 674, D 90), nys/nis 'is not' (796, Skeat 675, D 90), wæteru/wætru 'waters' (803, Skeat 680, D 91); morphological changes: unwurðan/unwurðum 'unworthy' (797, Skeat 675, D 90), wæteru/wæter 'waters'/'water' (805, Skeat 682, D 91); changes in word order: idel heonone/heonon idel 'from here in vain' (792793, Skeat 671-672, D 90), wynsumigendum gefean/gefean wynsumigendum 'exulting joy' (801, Skeat 678-679, D 91); and the lexical change ea/wættru 'river'/'water' (796, Skeat 674, D 90).

Other examples of words copied in error in $\mathrm{W}$ include (in the first hundred lines or so) to under for underfonde 'receiving' (54, Skeat 44, D 7), westten for westen 'wasteland' (66, Skeat 54, D 9), gastlica for gastlicra 'spiritual' (genitive plural, 88, Skeat 72, D 12) and gecwedenem for gecwedenum 'spoken' (dative plural, 102, Skeat 82, D 14); of these, only the last was corrected by Scribe A. The same passage also has peawas for peowes 'servant's' (genitive singular, 17, Skeat 14, D 3) and the non-standard verb inflexion in awenda for awende 'turned away' (42, Skeat 34, D 6), irregular forms at odds with the the text's usual care in matters of inflexion.

\subsection{Minor Omissions}

$\mathrm{W}$ has a number of instances where a single word or phrase has been left out, resulting in a meaningless reading. Such accidental omissions include pam pe (or variant) after mid (159, Skeat 129, D 20), needed for sense in order to provide a conjunction corresponding to quando 'when' in the Latin (169); a noun (probably gewilnunga 'desire') needed to accompany the stranded preposition to (646, Skeat 554, D 74) in the phrase me eallunga præscende to pære hæmetes [...] 'completely tormenting me with the [desire] for sexual intercourse [...]', translating Latin ad desiderium 'to a desire' (625); in the sequence hu micel ic on minra agenre gesceawunge 'how much I in my own estimation' (821-822, Skeat 695, D 93), a verb phrase is required after ic, corresponding to inferior sim 'may be inferior' (722), in order to complete the sense.

In these examples, as elsewhere, the errors go uncorrected, though there are places where the sense has been made good by Scribe A during the correction process; for example, findan (598, Skeat 517, D 69) is inserted to provide an infinitive to accompany hwæt mihtest $p u$ 'what could you [find]' (translating quid invenis, 583-584); and me (631, Skeat 542, D 73) is inserted as a direct object 
for myngode 'reminded [myself]' (translating meipsam ad memoriam reducebam 'I brought myself back to the memory', 613).

\subsection{Significant Lacunae}

W also has three significant lacunae, a lengthy one at 303-353 (Skeat 246-292, D 35-40) and two shorter ones at 649 (Skeat 557, D 74) and 934-936 (Skeat 783785 , D 105). It is notable that in none of these instances is there any scribal indication of omission despite the obvious resulting solecisms.

The first of the shorter lacunae (649, Skeat 557, D 74) occurs in a part of the text not represented in $\mathrm{G}$ or $\mathrm{O}$, but it is clear that something is missing. W reads $p a$ ðе ic me sylfe ær of pære eorðan 'her whom I myself before from the ground' (with no finite verb). The scribe has accidentally omitted something after $i c$, and it is apparent from the Latin that the gap amounts to more than a word or two. There is nothing in the Old English corresponding to

quae me fidedixerat, minaci me conpellatione exagitare furentem, quasi prevaricanti, et paenas prevaricationis mihi inminentis iram mucronis contra me agentem. Non enim antea surgebam de terra (628-632)

'who had acted as my guarantor would truly stand by me and furiously scold me with a threatening reprimand, as a violator of my duty, and that as a punishment for my violation of duty she would bring against me the anger of a menacing sword. I used not to get up from the ground before'.

The Old English renders quae 'who' but then immediately skips on to antea [...] de terra 'from the ground before' (me sylfe ær of pære eorðan). This error may be due to haplography: perhaps two occurrences of me or me sylf a few lines apart in the exemplar misled the W scribe.

The missing text in the other shorter lacuna (934-936, Skeat 783-785, D 105) can be supplied from $G$, though the deficiency would have been apparent even without $\mathrm{G}$, as the sense of the $\mathrm{W}$ text is jumbled. W has omitted

to begangenne ne ic efstan ne mæg swa myccles siðfætes hider to bringanne. Ac pu nu mid pære godcundan hæse pis weorc

'[nor have I anything suitable] to carry out [this task], nor am I able to rush away on so great a journey to bring anything here. But you [do] this task now in accordance with the divine command'

translating 
nec congruum quid habeo ad hoc opus exercendum, et iterum ityneris tanti longitudinem properare non valeo ut adferam. Tu divino iusso hoc opus [...] facito (874-877)

'nor do I have anything suitable for carrying out this task, and I do not have the strength to cover the distance of such a journey. By divine command, you perform this task'.

This whole sequence is lacking in $\mathrm{W}$ due to haplography: the words immediately preceding the Old English passage are pis weorc and the scribe has carelessly skipped from one instance of this noun phrase to the next.

In the case of the longer lacuna (303-353, Skeat 246-292, D 35-40), about two thirds of the missing text (approximately 430 words) can be supplied from $\mathrm{G},{ }^{17}$ but we lack an equivalent to 144 words of the Latin source (Latin 347-376) where G breaks off. The $\mathrm{W}$ scribe has jumped from a passage of narrative to the middle of a speech, thus producing a garbled reading: Đa arisan hi butu of pære eorpan $p a$ Jincg pe be me synd sona pu flihst fram me 'Then they both arose from the earth the things concerning me you will at once flee from me' (303 and 353-354, Skeat 246 and 318, D 35 and 41: the lacuna comes between eorpan and $b a$ ðincg). It is unclear why the scribe has committed such a gross error but it is not inconceivable that he or she has accidentally skipped a page of the exemplar: some 575-600 words are missing in $\mathrm{W}$, which could correspond to the number of words in a manuscript folio (on average, there are about 280-300 words to a side in $\mathrm{W}$ itself). Bussières (2004: 144) additionally notes that the one and a half sides remaining blank in the manuscript after Saint Mary of Egypt would have accommodated the missing passage. She suggests that the compiler estimated the right amount of space needed for the Life but reckoned without the unfortunate lacuna (and, one might add, the other lacunae in the text). ${ }^{18}$

\section{Textual Disagreements between Cotton Julius E.vii and the Other Manuscripts}

The other two manuscripts, $\mathrm{G}$ and $\mathrm{O}$, also have minor scribal slips here and there (see notes 15 and 16), as is the case with most manuscripts of Old English. It is

17 Some of the text of $\mathrm{G}$ is irrecoverable due to damage to the manuscript, so that the number of missing words in $\mathrm{W}$ is slightly higher than this figure.

18 As mentioned below (p. 388), there is also a significant lacuna at the end of Seven Sleepers; since this would not have fitted into the blank page and a half along with the missing Mary of Egypt material, the scribe's estimation about the amount of space needed must have been made after the copying of Seven Sleepers. 
clear, however, that $\mathrm{G}$ and $\mathrm{O}$ generally preserve the sense of the original Old English translation better than W. Most textual disagreements between W and G or $\mathrm{O}$ can be attributed to mistaken readings in $\mathrm{W}$.

\subsection{Unattributable and Attributable Minor Disagreements between $\mathbf{W}, 0$, and $G$}

Some disagreements are not securely attributable. These include minor contrasts in word order, such as $\mathrm{W}$ ahydde on eorðan versus $\mathrm{O}$ on eorðan ahydde 'hid in the ground' (18, Skeat 15, D 3), W pær sylf versus 0 self pær 'there [him]self' (33, Skeat 27, D 5), and W wæs swiðe onæled versus 0 swiðe wæs onhæled 'was very much inflamed' (376, Skeat 336-337, D 44): here one reading is as likely as the other and either scribe could have (probably unconsciously) changed the order; we might speculate, however, that since $\mathrm{W}$ departs from the inherited text in so many other respects, it is likely that it is also responsible for the changed word order. Also unattributable are trivial synonymic substitutions (probably also unconscious), such as in W gepancum versus O gepohtum 'thoughts' (59, Skeat 48, D 8) and W ophrinon versus G æthrinen 'touched' (522, Skeat 456, D 61), again one reading being as likely as the other. ${ }^{19}$

Examples of words copied wrongly in $\mathrm{W}$ but correctly in $\mathrm{G}$ and/or $\mathrm{O}$ include forð at 564 (Skeat 490, D 65) instead of for 'went', as in G/O (this is in the passage found in all three manuscripts); at 566 (Skeat 491, D 66) W pær 'there' is written for the G/O relative pronoun $p a / ð a$; at 571 (Skeat 495, D 66) W has towriðenne, an inflected infinitive, where a participle is required, as in 0 towripende/G togewriðende 'twisting'; at 277 (Skeat 226, D 33) W has hine 'him' where G has the required feminine form $h i$ 'her'; at 292 (Skeat 238, D 34) W has deap 'death' where $\mathrm{G}$ correctly has the adjective dead 'dead'. An instance in which both $\mathrm{O}$ and $\mathrm{W}$ have an incorrect reading is at 564 (Skeat 490, D 66), gemette ic sum man 'I met a certain man', where $\mathrm{G}$ has the grammatically correct sumne.

In these and numerous other instances it is obvious from the sense that $\mathrm{W}$ is in error. Elsewhere, however, both variants make tolerable sense. In such cases, comparison with the Latin source often indicates which reading must have been original. Thus, at 414 (Skeat 367, D 48), confusing $\langle\mathrm{p}\rangle$ and wyn $\langle\mathrm{p}\rangle$, W reads swingle 'whip' instead of spinle 'spindle', as in 0 (translating Latin fusum, 427); at 447 (Skeat 394, D 52), miscopying $s$ as c, W has wyrcum 'works' instead of wyrsum 'worse' (translating peioribus, 457); at 548 (Skeat 477, D 64), misreading another

19 For a discussion of purposeful synonymic substitution in the Life, see Magennis (2020). 
letter in its exemplar, W reads forðoht 'despaired of' instead of forworht 'sinner', as in G (the latter translating peccatrix, 542); and at 941 (Skeat 789-790, D 106), accidentally repeating tearum from the preceding phrase, $\mathrm{W}$ mistakenly has mid forðagotenum tearum 'with tears poured forth' instead of mid forðagotenan benum 'with prayers poured forth' (translating effusa prece, 882), as in G.

\subsection{Accidental Omissions in W}

Likewise, the accidental omission of words or phrases in $\mathrm{W}$ can be discerned by reference to $\mathrm{G}$ and/or $\mathrm{O}$ in overlapping passages. Here the appearance of an equivalent word or phrase in the Latin often provides confirmation that it is $\mathrm{W}$ that is deficient, rather than $\mathrm{G}$ or $\mathrm{O}$ having added something to the inherited text. Among numerous instances of omission in $\mathrm{W}$, in passages paralleled in $\mathrm{O}$, are the following: at 33 (Skeat 27, D 5) 0 manige [wisan] 'many [practices]' reflects Latin multa (45) but W omits the adjective; ${ }^{20}$ at 70 (Skeat 57, D 10) 0 pu wunne . 7 pu [...] wele pone munuclican ryne gefyld[:::] 'you have fought and you have well fulfilled the monastic course' corresponds to Latin decertasti, bene cursum monachi consummasti (80) but, apart from gefyldest, this passage has been omitted in $\mathrm{W}$, the scribe having evidently skipped from one second-person verb (wunne) to the next (gefyldest) in a form of grammatical haplography; at 611 (Skeat 527, D 70) the 0 phrase forpam pe ic ondrad [:] 'because I fear', translating timeo enim (595), is lacking in W.

Similar omissions are also scattered throughout the $\mathrm{W}$ passages overlapping with $\mathrm{G}$ but are notably more common in the final page or so of the text (934-960, Skeat 783-806, D 105-108); this passage of some thirty-five lines has the significant lacuna to begangenne [...] weorc 'to undertake [...] work' (934-936, Skeat 783-785, D 105), the missing phrase mid ege and lufan and micelan geleafan 'with fear and love and great faith' (953, Skeat 799, D 108), translating cum timore et amore magna fide (894) 'with fear and love with great faith', and no fewer than eleven omitted words or short phrases that appear in G. The W scribe seems to have become particularly casual with the end in sight.

The eleven omitted words and phrases are do 'do' (936, Skeat 786, D 105), translating facito (874); lichaman '[the saint's] body' (940, Skeat 788, D 106), translating [sanctae] corpusculum (881); limu 'limbs' (946, Skeat 793, D 107), translating membra (886); panon 'thence' (946, Skeat 794, D 107), though this might also be a $\mathrm{G}$ addition, since there is no equivalent in the Latin (887); gewat 'departed' (947,

20 The same adjective is again omitted in $\mathrm{W}$ at 36 (Skeat 29, D 5), where O manega [munucas] 'many [monks]' reflects multi (49). 
Skeat 794, D 107), translating recedunt (887); ealle 'all' (951, Skeat 797, D 108), translating omnia (891); abbod 'abbot' (954, Skeat 801, D 108), translating abbas (895); gerihte 'corrected' (956, Skeat 803, D 108), translating convertit (897); gefylde 'completed' (957, Skeat 803, D 108), translating implevit (898); mid sibbe 'with peace' (958, Skeat 804, D 108), translating in pace (899); a butan ende 'ever without end' (960, Skeat 806, D 108), though there is no Latin equivalent here (902).

\section{Purposeful Changes to the Text of Saint Mary of Egypt in Cotton Julius E.vii}

The textual contrasts highlighted in the previous section are due to instances of miscopying evident in W. On many other occasions, however, it is apparent that $\mathrm{W}$ has readings which have purposefully tweaked the inherited text. I have explored one such type of intervention elsewhere, the deliberate substitution of one word or phrase for another (Magennis 2020). For example, W twice reads forligeres 'fornication' where O has geligres (379 and 383, Skeat 339 and 343, D 44 and 45): here, in my view, $W$ or a predecessor has sought to improve the inherited text by replacing a rare word with one in common use in Late West Saxon; similarly, at 436 (Skeat 386, D 51) W reads unrihtlican 'wrongful' where O has unrihtwislican, a word found only in the Life, here and at 611 (Skeat 526, D 70).

Such substitutions are for reasons of considered linguistic preference, prompted by the lexical idiosyncracy of the original Saint Mary of Egypt translation, which has distinctively Anglian and other non-standard features. A possible example in $\mathrm{W}$ of a substitution made with a view to literary effect is gereccenne 'relate' (365, Skeat 327, D 43), in the passage in which Mary begins to tell Zosimus about her sinful past: here $\mathrm{O}$ gemyndgianne 'remember' is closer to Latin considerare 'consider' (388), but the change of verb adds an element of immediacy to the scene, as Mary highlights her relationship with Zosimus, rather than her own recollection.

$\mathrm{W}$ also has words and phrases not in $\mathrm{O}$ or $\mathrm{G}$ that amplify or clarify inherited readings.

\subsection{Instances of Purposeful Change in W/O Passages}

In passages overlapping with 0 , at 44 (Skeat 36, D 6) mærsung 'exaltation', in the sequence pæt wæs sealmsang, mærsung and haligra gewrita smeagung 'that was the singing of psalms, exaltation, and the study of holy scriptures', is surely an addition in $\mathrm{W}$, providing an amplifying detail: there is no corresponding word in 
O or in texts of the Latin original (cf. 58); at 69 (Skeat 56, D 10) W reads sum engel 'some angel', while $\mathrm{O}$ reads sum 'someone', and there is no word corresponding to engel in texts of the Latin original (compare Latin, 78, 87: quidam): I take engel to be an added clarifying detail;:' at 428 (Skeat 378, D 50) 0 man 'man' translates homo (441) but by way of clarification W changes man to Zosimus; here we can be confident that man is the original reading.

The most striking apparent $\mathrm{W}$ addition in passages also surviving in $\mathrm{O}$ is at 574-575 (Skeat 498-499, D 67), where and pære æfenrepsunge genealæhte 'and it approached nightfall', a phrase unparalleled in 0 or the Latin source (566), rhetorically amplifies the image of sunset in the sequence and sunne hi pa to setle ahylde, and pære æfenrepsunge genealæhte 'the sun went down in its setting, and it approached nightfall'. It is possible that, rather than being contributed by W (or a predecessor), the phrase was part of the original translation but was accidentally omitted in $\mathrm{O}$, though we have observed that omissions are far less frequent in $\mathrm{O}$ than in $\mathrm{W}$.

Other likely $\mathrm{W}$ additions in passages also extant in $\mathrm{O}$ are pæt hi me pe hrædlicor underfon 'that they may receive me the more readily' (400, Skeat 357, D 47); swa in the phrase swa cwyce 'thus alive' (437, Skeat 387, D 51); gedeð pe on hine gelyfad 'causes [to be safe] those who believe in him' (441, Skeat 390, D 51); Sancta Marian, qualifying lættewestran 'guide' (585, Skeat 508, D 67); ealle 'all [those who turn to him]' (589, Skeat 511, D 68); mannum 'men', providing an indirect object for gifað 'gives' (726, Skeat 617, D 82), which in 0 is used intransitively; wisan 'practices' in sume wisan 'some practices' (745-746, Skeat 634, D 85). These words and phrases are unparalleled in $\mathrm{O}$ and have no equivalents in the Latin.

\subsection{Instances of Purposeful Change in W/G Passages}

Similarly in passages overlapping with G, W includes clarifying and amplifying details not in the other manuscript and not paralleled in the Latin. These include adverbs such as soðlice 'truly' at 290 (Skeat 236, D 34) and nu 'now' at 504 (Skeat 441, D 59) 22 and the adjective/participle æteowod, in Beo me nu hælo latteow æteowod 'Be now a guide to salvation appearing to me' (551-552, Skeat 480-481, $D$ 64), where the addition is perhaps meant to be clarifying but seems somewhat otiose. At 531 (Skeat 463, D 62) W has added a noun, duru, in the phrase pæs

$21 \mathrm{~W}$ also has se engel 'the angel' (79, Skeat 64, D 11), where $\mathrm{O}$ is indecipherable.

22 Also swa 'so' (500, Skeat 438, D 58); eft 'again' (529, Skeat 462, D 62); ær 'before' (924, Skeat 775, D 104); hider 'hither' (930, Skeat 780, D 105). 
inganges duru bewerede 'blocked the door of the entrance', in which duru amplifies (unnecessarily) the $\mathrm{G}$ reading pæs inganges bewerede 'blocked the entrance' (with the verb taking a genitive object: see $D O E$ s.v. bewerian 3.a.ii).

There are also a number of longer $\mathrm{W}$ phrases lacking in $\mathrm{G}$ and without a counterpart in the Latin. For example, at 270 (Skeat 220, D 32) W has pe heo mæst mihte and mæst neod wæs 'that she was most able to and which there was most need [to conceal]', amplifying the $\mathrm{G}$ reading (as emended by Earle 1861) pe hire mæst neod wæs 'that there was most need for her'; at 492-493 (Skeat 431-432, D 57) it has the added phrase and cweðende 'and saying', filling out the implied sense of the original; at 527 (Skeat 460, D 61) it adds and ic pa ineode 'and I then went in', specifying an action understood but not stated in the Latin.

Other $\mathrm{W}$ additions in passages also in $\mathrm{G}$ are God sy gebletsod, se ðe is hælo tiligende 'blessed be God, who is working for salvation' (300-301, Skeat 244-245, D 35): here se ðe is, which turns an adjectival phrase into a relative clause, is lacking in G; forworht eom, pæt ic 'I am a sinner, that I [should behold]' (496, Skeat 434, D 57): W turns G's single word forworht into a clause; gefærst and 'obtain and' (556, Skeat 484, D 65): an additional phrase amplifying the narrative (though this insertion might also be due to dittography since the similar-looking oferfærst 'cross over' appears in the preceding clause); gewæht eom pæt ic delfan ne mæg 'I am weakened so that I cannot dig' (933, Skeat 782-783, D 105): here eom pæt ic, not in G, appends an explanatory clause to the adjective; mid hire clifrum earmum 'with its claws [and?] arms' (938, Skeat 787, D 106): W is more specific than G (or the Latin, 880), adding clifrum, not in $\mathrm{G}$, though the resulting syntax is clumsy (perhaps the scribe intended to replace earmum with clifrum but ended up keeping both words).

\section{Scribal Practice in the Second Half of the W Legend of the Seven Sleepers}

As noted above, the W Saint Mary of Egypt scribe also copied the second half of the immediately preceding item in the manuscript, the Legend of the Seven Sleepers (426-772, Skeat 468-840, D 69-122); the first half of Seven Sleepers is written by a different scribe, Scribe B. Parts of Seven Sleepers survive also in O, though only thirty-six lines (16-47, Skeat $17-53$, D 3-8) of recoverable text are available for comparison with the Scribe B passage. ${ }^{23}$

23 As with Saint Mary of Egypt, I leave out of consideration changes in word order, since these are unattributable, but such changes are very rare anyway: I count only two clear cases, W gebletsige 
The second half of Seven Sleepers displays the same kinds of slips and omissions that we have seen in Saint Mary of Egypt (see Section 3, above), though not as frequently. Thus, Seven Sleepers has ephefe instead of ephese 'Ephesus' (501, Skeat 549, D 79), fædunga instead of færunga 'suddenly' (575, Skeat 628, D 92), teadest instead of tealdest 'mention' (649, Skeat 706, D 102), among a scattering of such instances (all three of these are uncorrected by Scribe A, while ephefe and teadest are corrected by the point corrector). Omissions include single words, present in O, such as wæs 'was' (469, Skeat 513, D 75), required to provide a finite verb in the verb phrase he [wæs] wundrigende 'he was wondering'; betst 'best' (533, Skeat 583, D 84), needed as a nominal in the vocative phrase ealra manna [betst] '[you] best of all men'; nan 'no' (573, Skeat 626, D 91), providing a negative in the clause hine [nan] man ne cuðe gecnawan 'no one could recognize him'.24

$\mathrm{W}$ also omits longer phrases that are present in $\mathrm{O}$. To give three examples out of a half-dozen such instances, at 481-482 (Skeat 527-528, D 77), in the sequence written in $\mathrm{O}$ as pær gehwilce menn heora ceap beceapodan, pa gehyrde he hu pa menn hiom betweonan spræcon 'where people were all selling their wares, he heard everyone talking among themselves' W omits men heora ceap beceapodan, pa gehyrde he hu pa menn, evidently jumping from one verb to the next: the image in $\mathrm{O}$ of market trading is taken from the Latin original (vendentes panes 'selling loaves', 252) and gehyrde is one of a series of verbs of perception in a vivid passage highlighting the plight of Malchus, one of the seven saints. Similarly, at 516 (Skeat 578, D 84) O reads pa he beheold swype georne pa cypemenn hu georne hy hine beheoldan 'there he observed very carefully how the merchants carefully observed him', reflecting the Latin original, videbat eos considerantes in invicem 'looked at them as they examined him in turn' (256): here W has pa beheold swiðe pa cypemen hine, an ungrammatical reading which seems to be the result of haplography (behealdan and georne). ${ }^{25}$ And at 741-743 (Skeat 807-809, D 118) the sequence in $\mathrm{O}$ pæt pu us woldest on eorðan pinre rihtwisnysse sunnan oneowan and us on pam wræcsiðe onlyhtan pyre micelan mildheortnysse leoman 'that you were willing to reveal the sun of your righteousness to us on earth and to give us light

me as against $\mathrm{O}$ me gebletsige 'bless me' (476, Skeat 522, D 76) and W to us cume swa pu rapost mæge as against $\mathrm{O}$ swa pu rapost mæge to us cuman wille 'as quickly as you can that you [will] come to us' (730, Skeat 794, D 115) (the latter also incorporating a slight grammatical change); also unattributable are apparently reflexive word substitutions, such as W wintra/O geara 'years' (444, Skeat 487, D 71) and W gemynde/O gewitte 'mind' (581, Skeat 634, D 93); I count six such incidences.

24 In these examples the point corrector emends the unsatisfactory $\mathrm{W}$ text, adding pohte 'thought' after wundrigende 'wondering, he thought', inserting betst, though unidiomatically out of position in the next phrase (ealra manna bruce ge betst 'of all men keep best'), and supplying the required nan.

25 The point corrector emends W beheold to beheoldon. 
on our journey of exile through the radiance of your great mercy' is cut short in W, with rihtwisnysse sunnan oneowan and us on pam wræcsiðe onlyhtan pyre micelan omitted and oneowan supplied after leoman: presumably the scribe has skipped from one -nysse word to the next; the authority of the $\mathrm{O}$ reading is confirmed by presence of an image of the shining sun in the corresponding Latin text (solem iustitiae irradiasti nobis 'you have caused the sun of justice to shine for us', 346).

And $\mathrm{W}$ has a major lacuna. The text suddenly comes to an end at a point corresponding to the middle of a speech in the Latin (769, Skeat 838, D 121), thus omitting the legend's conclusion, which recounts the glorification of the saints (the corresponding passage in the Latin contains about 250 words). The usual explanations for lacunae, i.e. haplography and eye-skip, do not apply, but could the scribe have been misled by the note of finality in the closing sentence of the existing text, thinking this was the actual end (especially if it happened to coincide with the end of a page)? We can only speculate, but it is notable that the existing text concludes with the somewhat doxology-like pe on his naman wið ealle fynd gescylde, ge on pisson life ge on pæm toweardan '[may God] shield you against all enemies, both in this life and in that to come' (768-769, Skeat 837-838, D 121). ${ }^{26}$

That the same kinds of errors and omissions occur in the second half of Seven Sleepers as in Saint Mary of Egypt is hardly surprising, since the same scribe copied both texts: what is surprising is the sheer number of such slips in Saint Mary of Egypt. Almost completely lacking in the second half of Seven Sleepers, on the other hand, are instances of seemingly purposeful intervention like those we have identified in Saint Mary of Egypt. Like Saint Mary of Egypt, Seven Sleepers has a number of trivial synonymic contrasts (for example, $\mathrm{W}$ wintra as against $\mathrm{O}$ geara 'years', 444, Skeat 487, D 71, and W cwæð as against O sæde 'said', 561, Skeat 612, D 89) but there is only one possible instance in it of lexical substitution on stylistic grounds or because of linguistic preference, geandwyrde for $\mathrm{O}$ andswarude 'answered' (557, Skeat 607, D 88), a type of editorial intervention notable in the Saint Mary of Egypt text. ${ }^{27}$

Also characteristic of Saint Mary of Egypt, as we have seen, is the occurrence of words and short phrases, and indeed some longer phrases, added to the text as it appears in $\mathrm{G}$ and $\mathrm{O}$ and without parallel in the Latin source. No such additions are apparent in Seven Sleepers. We can identify a good number of departures from the inherited text but they are not due to purposeful scribal intervention. ${ }^{28}$

26 After the existing text, the scribe left an empty line and then went straight on to copy Saint Mary of Egypt.

27 As discussed in detail in Magennis (2020).

28 There is one seven-word passage that appears in $\mathrm{W}$ but not in $\mathrm{O}$, [hine panon ealle atugon tomiddes pære] cypinge, and hine man heold onmiddan pære [byrig] '[they all dragged him from there 


\section{Scribe A and 'Scribe C'}

In this section, I broaden the picture by comparing scribal performance in the 'Scribe C' texts, Saint Mary of Egypt and the second half of Seven Sleepers, to that in Scribe A lives. Bussières (2007: 67-69) explains that the performance of Scribe $A$ is somewhat uneven across the manuscript, but in key respects it conforms to that of 'Scribe C'; and, as I pointed out earlier (p. 376, above), both stints are similarly consistent in generally adhering to the norms of Standard Old English.

Seven Sleepers has more errors and omissions than the Scribe A lives, which perhaps suggests that its scribe was working under increased pressure, but the errors and omissions are not different in nature from those that occur elsewhere. What we do not find in Scribe A texts (or Seven Sleepers) is the scale of textual deficiencies of Saint Mary of Egypt; nor do we see the kind of purposeful intervention apparent in the latter life, aimed at 'improving' or otherwise changing the inherited text. The major scribal contrast evident in $\mathrm{W}$, therefore, is not between Scribe A and 'Scribe C' but between Saint Mary of Egypt and the rest of the manuscript.

To illustrate scribal performance it will be convenient to consider as a sample of Scribe A's work those lives also represented in O, Ælfric's Saint Eugenia, Saint Basil, Saints Julian and Basilissa, and the non-Ælfrician Saint Euphrosyne. ${ }^{29}$

\subsection{Alfric's Lives}

Though it has some orthographic quirks, most notably a profusion of $æ$ for $e$ spellings, ${ }^{30}$ Saint Eugenia is mostly copied carefully, more faithfully indeed than the 0

into the middle of the] marketplace, and he was held there in the middle of the [city]' (559, Skeat 608-609, D 88), but the obvious explanation for this discrepancy is haplography in 0 rather than addition in $\mathrm{W}$ : the $\mathrm{O}$ scribe has jumped from one tomiddes/tomiddan pære to the next (compare Latin, trahebant eum per plateam civitatis, et tenebant eum in medio 'they dragged him through the streets of the city, and held him in the midst', 268-269).

29 These texts in 0 are copied by the same hand that wrote Mary of Egypt and Seven Sleepers in that manuscript, one of several different $O$ hands identified by Ker (1957). As well as appearing in Skeat (1881-1900) and Clayton and Mullins (2019), Basil is edited and translated by Corona (2006) (with the same lineation as CM; both Corona and CM depart from Skeat by one line at 22); Julian and Basiliss $a$ is also edited and translated by Upchurch (2007: 54-71) (with run-on lineation, not referenced here).

30 There are nine in the first twenty lines alone: dæhter 'daughter' (2), pægn/ðægn 'thane' (5, 12), ægyfto ‘Egypt' (10), gesætnysse ‘decrees' (11), æhtnyss 'persecution' (14), twægen 'two' (16), særgium 
copy. ${ }^{31}$ As well as the $e / æ$ assimilations, it has the usual minor inconsistencies in inflexions and many $i / y$ interchanges. Among its few slips, it omits pærrihte 'straightaway' (138) and eall 'all' (139) (as in 0) and writes ægyfto for ægypto 'Egypt' (10), æfter pysum wordum 'after these words' for æfter pysum wurdon 'after this, they were [seized]' (369, CM 370), and awelde for acwealde 'killed' (362, CM 363), the latter corrected by Scribe A.

Saint Basil and Saints Julian and Basilissa also have good texts. They have the same traits noted by Gretsch (2003) for the manuscript as a whole (see above, p. 377) but little in the way of error: Saint Basil curiously has the wrong grammatical gender on a few occasions: seo hælend 'the saviour' (66, CM 65), seo biscop 'the bishop' (71, CM 70; and 77, CM 76), pine dyrstignysse 'your presumption' (225, CM 224), and heo instead of he 'he' (30), and the irregular spelling pewas (353, CM 352), corrected by Scribe A to peowas 'servants'; and there is one instance of (trivial) word substitution, W pearle as against O swyðe 'very much' (253, CM 252) (either of which could be the original reading). ${ }^{32}$ Saint Basil also has a number of verb endings in - $a$ instead of $-e$, a non-standard feature that we noted (above, p. 379) in Saint Mary of Egypt: thus smæda for smeade 'considered' (299, CM 298), tæhta 'taught, prescribed' (421, CM 420), gehyra '[I] hear' (431, CM 430), gehæleda 'healed' (487, CM 486).

Saints Julian and Basilissa also has grammatical gender problems in a few places: se æhtnysse 'the persecution' (88), se unwynsumnyss 'the unpleasantness' (215, CM 216) and agenre for agenne 'own' in agenre sunu 'own son' (206, CM 207); it also has wurðian where the finite form wurðiap 'honours' (135) (as in 0 ) is required, and it mangles geedcucode 'brought back to life' (413, CM 414) as geedcutode and cwearterne 'prison' as cwearterterne (231, CM 232). There is one deliberate change in vocabulary in this text: the scribe (or a predecessor) seems to have balked at the unusual word anwealg 'uncorrupted' in the exemplar and

\footnotetext{
'Sergius' (17), spræcap 'spoke' (18). Eugenia also has the rare spelling dryhten for drihten 'Lord' (40) (historically correct).

31 O is 'significantly different' from W (Clayton and Mullins 2019: I, 343): it highlights issues of (natural) gender throughout (Eugenia spends part of the story disguised as a male in a monastery), most notably in the episode where the widow Melantia accuses her of sexual assault, and adds other amplifying details such as on golde in the phrase on lande and on golde and on feo 'in land and in gold and in money' (156, CM 157), also rewording to eugeniam his agenre dehter 'to Eugenia his own daughter' to to bam abbode pe wæs his agen dohter and he pæt niste 'to the abbot who was his own daughter and he did not know it' (201).

32 Basil also has one vocabulary disagreement between $\mathrm{W}$ and $\mathrm{O}$ affecting sense, $\mathrm{W}$ gastas 'spirits' as against O lustas 'pleasures' (385, CM 384) but this is due to an error in O, since lustas makes unsatisfactory sense in the context and lacks the required $g$ alliteration.
} 
substituted the more current synonym ansund 'uncorrupted' (43). ${ }^{33}$ Saints Julian and Basilissa has one occurrence of $-a$ for $-e$ in a finite verb inflexion, ic gelyfa 'I believe' (204, CM 205), and one instance of loss of $h-$, reppan 'touch' (405, CM 406).

\subsection{Saint Euphrosyne}

These three Ælfric lives present relatively few textual problems. They come at the beginning of the manuscript, where the scribe proceeds with considerable care, producing a reasonably clean text. Saint Euphrosyne comes towards the end of the collection and is even more like Seven Sleepers in its scribal performance. It has a sprinkling of words wrongly copied, such as gymenne for gemynne 'memory' (54, D 10), wyxst for wyxð 'grows' (228, D 36) and gehyltan for gehyhtan 'hope' (hylt 'holds' had occurred in the previous line) (273, D 43); like other lives in W it also confuses pone and ponne (see above, note 13). It also has words accidentally omitted, such as syllan 'give' (41, D 7) (inserted by Scribe A as a correction), æfter 'after' (59, D 11) and hwæt 'what' (179, D 29), all needed to complete the sense, and a number of phrases present in $\mathrm{O}$ but lacking in $\mathrm{W}$ : examples are gefean he hine underfehð '[with] joy will he receive him' (67, D 13) and dydon pe nænne 'should do it who [have] no [faith]' (84, D 15), again both needed to complete the sense. ${ }^{34}$

Saint Euphrosyne is also comparable to Seven Sleepers in the number of synonyms its two texts display, both these lives (as also Saint Mary of Egypt) having more such instances than Saint Eugenia, Saint Basil, and Saints Julian and Basilis$s a$. In most cases we cannot tell which version has the changed reading ${ }^{35}$ and in

33 See further Magennis (2020: 811); there is one further vocabulary disagreement, W wyssunga '[at God's] direction' as against O willan '[according to God's] will' (81), where the change of meaning is minimal and either reading could be the original one.

34 Incidentally, although there are no instances of wrong grammatical gender in Saint Euphrosyne, one phrase is notable for its ironic gender implications. Euphrosyne, in the character of the monk Smaragdus, consoles her unwitting father Paphnutius about the loss of his daughter (i.e. herself). In a context rich in dramatic irony the monk expresses the hope that Paphnutius will find some consolation purh me eaðmodre 'through me, humble as I am' (253, D 40). Here, Euphrosyne nearly gives the game away, but Paphnutius does not pick up on the fact that the monk refers to himself in the feminine gender. This touch is likely to be an authorial rather than a scribal contribution.

35 Two changes that seem attributable are O ondræde 'fear' for W onsitte 'oppress' (75, D 14), where $O$ may be seen to replace a word uncommon in Late West Saxon with one familiar in Ælfric, and 0 sæde 'said' (243, D 38) for W trahtnode 'expounded', where trahtnode reflects Latin interpretans 'expounding' (649 A). 
most cases the changes seem fairly inconsequential anyway: examples are W Loca as against O Efne 'Look/Behold' (85, D 15) and W gewiten as against O gefaren 'departed' (103, D 18). Synonyms are worth mentioning, however, since they provide another resemblance between Scribe A and 'Scribe C'.

Notable in Saint Euphrosyne are the spellings hio 'she' (28, D 5; and 191, D 31), as well as heo, and sio 'that [person]' (291, D 46), as well as seo. And there is one distinctive feature that Saint Euphrosyne shares with Saint Eustace and also with the second half of Seven Sleepers, occasional loss of $n$ before $r$ in the possessive pronouns min 'my' and pin 'your': it has mire (201, D 32; and 228, D 36), mira (193, D 31) and pire (219, D 35; and 249, D 39). ${ }^{36} \mathrm{Hio} /$ sio and mire/pire spellings are not found in Saint Mary of Egypt.

Before ending this section, we might briefly note one feature of Saint Euphrosyne in $\mathrm{W}$ that sets it apart from the rest of the lives in the collection: it has a number of passages that abbreviate the original translation. For example, at 89 (D 16) W reads

swa he pone munuc geseah, pa axode he hine to hwi he come. Pa sæde he him pæt hit wære pæs abbodes hadingdæg and he to him cuman sceolde to his bletsunga

'when he saw the monk, he asked him why he had come. He said to him that it was the abbot's ordination day and that he was to come to him to receive his blessing'.

Instead of this, $\mathrm{O}$ has

swa he geaxode pa axode he hine, "Broðor to hwi [...] hidere to us?” Đa cwæð se broðor, “Hit is ures abbodes hadungdæg. Nu sende he me æfter be pæt pu cume [...] his bletsunge" [with some words irrecoverable]

'when he discovered him he asked him, “Brother, why [have you come] to us here?” Then the brother said, "It is our abbot's ordination day. Now he has sent me for you that you should come [to receive] his blessing”".

Here $\mathrm{W}$ has simplified the fuller $\mathrm{O}$ version by removing the direct speech, which in O reflects the Latin Vita Sanctae Euphrosynae (645, Section C). ${ }^{37}$

36 Saint Eustace has mire (212, D 29; 36, D 261; and 404, D 51) and pire (119, D 17; 211, D 29; and 337, D 44), Seven Sleepers mire (744, Skeat 810, D 118; and 745, Skeat 811, D 118) and byre (743, Skeat 808, D 118); the distinctive spelling agreements between Euphrosyne, Eustace and Seven Sleepers lead Ronald Torkar to conclude that these three anonymous texts were copied into $\mathrm{W}$ from the same exemplar: see Torkar (1971).

37 PL 73, 643-652. 
Likewise, at 94 (D 17) W reads

sende Eufrosina anne cniht swiðe getrywne hire to pam mynstre and bæd pæt swa hwilcne munuc swa he funde

'Euphrosyne sent an attendant who was very loyal to her to the monastery and asked that [he bring] whichever monk he found'.

Here again $\mathrm{O}$ has a more expansive variant:

sende Eufrosina anne cniht pone pe heo getreowost wiste and him to cwæð, "Far to Peodosies mynstre and gang into pære cyrcan and swa hwilcne munuc swa pu finde”.

'Euphrosyne sent an attendant whom she knew to be very loyal and said to him, "Go to the monastery of Theodosius and go into the church and [bring me] whichever monk you find"'.

Here too the longer version in $\mathrm{O}$ corresponds to the Latin Vita, which has the direct speech and the name Theodosius (645, Section D). ${ }^{38} \mathrm{~W}$ also has heo 'she' where $\mathrm{O}$ has pæt mæden 'the maiden' (65, D 13) and he where $\mathrm{O}$ has se bropor 'the brother' (67, D 13). Such deictic curtailment is a curious aspect of scribal performance in Saint Euphrosyne and is certainly a long way from the tendency towards amplification in Saint Mary of Egypt. Since it does not occur elsewhere in the manuscript, it has probably been inherited from an exemplar.

\section{A Different Performance: Scribe B}

The part of the Legend of the Seven Sleepers copied by Scribe B presents a strikingly different textual picture from that in the part copied by the other scribe. The Scribe B stint does have the 'peculiarities' identified by Gretsch (2003) for the

38 Note also 102-103 (D 18), where W has and his mæcca min modor is of pyssum life gewiten 'and his wife my mother has departed from this life', where $\mathrm{O}$ reads and he hædde gemæccan seo me on pas woruld acænde and heo his [sic] of pisum life gefaren 'and he had a wife who bore me in this world and she has departed from this life'; here the phrase omitted in W follows the Latin habuitque uxorem quae me genuit (645D); and 244 (D 39), where W has and heo cwæð ða git 'and she said then further', abbreviating the $\mathrm{O}$ reading Đa ongemang pysum ondred heo pæt heo [...] oncnawen and hire purh pæt [...] heo afrefrian, and pus cwæð (some words illegible) 'Then meanwhile she feared that she [would be] recognized and because of that [would not be able] to console him, and she said'; again the $\mathrm{O}$ reading reflects the Latin original, et timens ne agnosceretur 'and afraid lest she be recognized' (649A). 
manuscript as a whole ${ }^{39}$ and also a number of obvious errors of the kind we have seen elsewhere ${ }^{40}$ though comparatively few omissions of words ${ }^{41}$ and only one likely omission of a phrase; ${ }^{42}$ in the short passage extant in $\mathrm{O}$ as well as $\mathrm{W}$ there are no instances of synonyms or word substitution or of disagreement in word order.

The major distinguishing feature of the Scribe B stint, however, is that it is less strict in its spelling and inflexional morphology than is the case elsewhere in W. For example, it has many Weak Class II preterites in -ed- as well as the standard -od-, a rarity in the rest of the manuscript; it even has one occurrence of -ude, in getucude 'tormented' (14, Skeat 15, D 2), even rarer. ${ }^{43}$ It also frequently has Weak Class II present subjunctives and participles without medial $g$, as in ofaxie 'find out' (425, Skeat 467, D 69), hlosniende 'listening' (121, Skeat 136, D 20), also uncommon elsewhere in $\mathrm{W} .{ }^{44}$

39 Note, for example, $i$ for $y$ in birig 'city' (90, 186, Skeat 101, 205, D 14, 30) and clipode 'called' (141, Skeat 156, D 22), and $y$ for $i$ in mycelne 'much' (38, Skeat 43, D 7) and wylle 'will' (252, Skeat 277, D 40); $æ / e$ confusion is evident in ahwer for ahwær 'anywhere' (44, Skeat 49, D 7) and nahwer for nahwær 'nowhere' (245, Skeat 269, D 39); also the $e$ in hremmas 'ravens' (68, Skeat 77, D 11) is written over an erasure, surely of $æ$; among instances of levelling of inflexions in B are the forms blodigon bilon for blodigum bilum 'bloody beaks' (71, Skeat 80, D 11) and sceoldan for sceoldon 'should' (331, Skeat 363, D 54).

40 For example, in the opening lines alone it has eadriga for eadigra 'blessed' (1, Skeat 1, D 1) (uncorrected) and berhte for beorhte 'brightly' (2, Skeat 3, D 1) (corrected by Scribe A).

41 Among words omitted are $h i$ 'they' (47, Skeat 53, D 8) and syndon 'are' (131, Skeat 147, D 21), both of which are required for sense (and both inserted by the point corrector).

42 The phrase is and gyldene 'and of gold' (180-181, Skeat 199, D 29) in the sequence namon æt heora magon pa sceattas genoge, sylfrene and gyldene ungefoge 'received then from their kinsfolk money enough, abundant silver and gold': and gyldene is inserted by the point corrector and corresponds to the Latin tollentes aurum et argentum e parentibus suis 'taking gold and silver from their parents' (86), though the word order is different. The point corrector also inserts Đa cwæð se casere to ðam embstandendum 'Then the emperor said to those standing around' (251, Skeat 274, D 40) and pæs geuðe 'granted that' (285, Skeat 312, D 45), both of which enhance the sense but lack equivalents in the Latin (and, as is the case also with and gyldene, are not in passages paralleled in 0).

43 Saint Mary of Egypt has some instances of -ed-but usually only with verb stems ending in $r$, $l$ and $w$, for example besylede 'defiled' (384, Skeat 343, D 45), astyrede 'stirred' (424, Skeat 375, D 49), a rule also broadly followed in the second half of Seven Sleepers: getimbred 'built' (492, Skeat 539, D 78) (as well as getimbrode, 466, Skeat 511, D 74), heredon 'praised' (716, Skeat 779, D 113); Seven Sleepers also has -ed-after $w$ : tawedon 'abused' (599, Skeat 654, D 95), prowedon 'suffered' (725, Skeat 790, D 114); exceptions to this rule are gewilnedan 'longed-for' (Mary of Egypt 870, Skeat 731, D 98) and wafedon 'wondered' (Seven Sleepers 565, Skeat 616, D 90).

44 Mary of Egypt and the second part of Seven Sleepers have no forms without medial g. Forms with medial -g-in the Scribe B stint are ðreatige 'oppress' (266, Skeat 293, D 42) and geomrigende 'lamenting' (115, Skeat 129, D 18). 
Other notable features of this part of Seven Sleepers are the spelling -ngc for -ng after a front vowel, as in ciningce 'king' (127, Skeat 142, D 21), pingc 'thing' (9 times, including two ðingc) (62, Skeat 38, D 5, etc.) and lengc 'longer' (4 times) (101, Skeat 114, D 16, etc.), contrasting with 'Scribe C'/Scribe A's -ncg spelling, ${ }^{45}$ and the frequent loss of initial $h$ particularly in the groups $h l$ and $h r$, as in ryðera for hryðera 'cows' (30, Skeat 34, D 5) and lafordes for hlafordes 'lord's' (382, Skeat 419, D 62), but also before vowels, as in æpengylde 'idolatry' (28, Skeat 31, D 4) and ealdan 'hold' (142, Skeat 158, D 23; and 192, Skeat 212, D 31);46 in a reversal of this pattern, 'unhistorical' $h$ appears in hreafe, for reafe 'clothing' (359, Skeat 394, D 59). ${ }^{47}$ There are no examples of loss or insertion of $h$ in the rest of Seven Sleepers and only one in the Ælfrician texts considered above; ${ }^{48}$ we do, however, find several instances of this feature (though none of loss of $h$ before a vowel) in Saint Mary of Egypt. ${ }^{49}$

Finally, the Scribe B part of Seven Sleepers has a number of instances of incorrect or missing case endings, of a kind not acceptable in the most regular Late West Saxon. Examples are geleafa 'faith' (61, Skeat 69, D 10), eapelic 'scanty' (212, Skeat 234, D 34) and fæstheald 'firm' (386, Skeat 423, D 63), all masculine accusative. These solecisms, as also irregularities involving $h$, have been corrected in the manuscript, mostly by the point corrector, ${ }^{50}$ who also has many corrections written over erasures of suffixes, where the original reading is not legible; ngc spellings have been allowed to stand.

45 In the Scribe B stint we find no occurrences of pincg and only one of ping (205, Skeat 226, 33).

46 Also geyrdon 'heard' (259, Skeat 285, D 41), is 'his' (292, Skeat 320, D 47), beate 'threaten' (418, Skeat 459, D 68), as well as behate (also 418, Skeat 459, D 68). On loss and insertion of $h$, see Scragg (1970).

47 The correct form reaf also occurs (398, 399, Skeat 437, 438, D 65 (twice)), but in both cases an initial letter has been erased, surely $h$.

48 Julian and Basilissa has reppan for hreppan 'touch' (405, CM 406).

49 In Mary of Egypt $h$ is lost in opran 'touched' (854, Skeat 719, D 97) and oprinan 'touch' corrected by Scribe A to ophrinan (860, Skeat 723, D 97); a likely third instance is leahtrum for hleahtrum 'laughter' (423, Skeat 375, D 48): the meaning leahtor 'sin' is also possible here but 'laughter' corresponds better to the Latin (436). Instances of superfluous $h$ - in Mary of Egypt are hreowan 'rowed' (427, Skeat 378, D 50), ahrefnode 'endured' (610, Skeat 526, D 70), hrepsunge 'evening' (782, Skeat 663, D 88), hleorende ‘departing’ (896, Skeat 752, D 100), hleorde ‘departed' (907, Skeat 761, D 101; also 958, Skeat 804, D 108).

50 The correction of beate to behate is in the hand of Scribe A. 


\section{Conclusion}

This article has highlighted the distinctiveness of the W Life of Saint Mary of Egypt in its manuscript context. The W Life is distinctive in the poor quality of its text but also, paradoxically, in its purposeful departures from what must have been the original translation. Since such purposeful departures are not a feature of scribal performance elsewhere in the manuscript, including in the other 'Scribe C' text, the second half of Seven Sleepers, it is likely that they have been transmitted from an exemplar. Some of the many instances of miscopying and omission may also be due to an exemplar but, if so, they have been passed on unthinkingly. And it is manifestly the case that some errors are directly attributable to the $\mathrm{W}$ scribe, as in the disagreements in the passage mistakenly copied twice. The second half of Seven Sleepers also has more errors than is generally the case elsewhere in the manuscript but still far fewer than Saint Mary of Egypt has, and within Saint Mary of Egypt the errors increase in frequency as the text goes on, culminating in the last page or so, which has a constant stream of slips and omissions. The text of the second part of Seven Sleepers and Saint Mary of Egypt thus suggests a scribe working under heavy and increasing pressure.

Yet, apart from the error count, scribal performance in these two Lives is not markedly out of line with that of Scribe A. The Scribe B stint presents a different picture, as we have just seen in Section 8, but many of the same kinds of mistakes as we have noted in the second part of Seven Sleepers and in Saint Mary of Egypt occasionally crop up in Scribe A texts, and there is a general similarity in copying practice between Scribe A and 'Scribe C': they agree in their mostly attentive adherence to the norms of Late West Saxon and, within this, they share spelling traits, including Gretsch's (2003) distinctive orthographic markers. Saint Mary of Egypt contrasts with Scribe A's work in the volume of its copying deficiencies and in its instances of purposeful intervention, but it also contrasts with Seven Sleepers in these respects.

Saint Mary of Egypt is a unique text in W, inserted in the manuscript almost as an afterthought, but I find no evidence in the two 'Scribe C' texts, taken together, to contradict Bussières's (2007) contention, as first mooted by Ker (1957), that 'Scribe C' is identical with Scribe A. Saint Mary of Egypt, along with the second half of Seven Sleepers, was copied either by Scribe A, not at his or her best and perhaps contending with a difficult exemplar, or by a scribe with the same training and orthographic traits as Scribe A: the balance of probability must lie with Scribe A being 'Scribe C' ${ }^{51}$

51 I would like to thank Kevin Kiernan, Mary Clayton and the two anonymous Anglia reviewers for valuable comments and advice on the present article. I am also very grateful to the eagle-eyed editors of Anglia. 


\section{Appendix A: Extant Texts of Saint Mary of Egypt}

W (Ker 1957: no. 162), fols. 122v-136r, complete text, with three notable lacunae:

major lacuna, fol. $127 \mathrm{r}$

(303-353, Skeat 246-292, D 35-40)
G (Ker 1957: no. 117), three fragments:

O (Ker 1957: no. 177), four fragments, plus incipit and explicit, as transcribed by Wanley (1705):

first O fragment, fols. 25 (26) and 26 (56) (12-123, Skeat 11-99, D 2-16)

first $\mathrm{G}$ fragment, fol. 4 (268-352, Skeat 219-292, D 32-40)

second $\mathrm{O}$ fragment, fols. 27 (16) and 28 (17) (354-456, Skeat 318-456, D 41-53)

second $\mathrm{G}$ fragment, fol. 5 (488-572, Skeat 428-497, D 56-67)

third O fragment, fol. 29 (15) (557-614, Skeat 484-529, D 65-70)

short lacuna, fol. 131v (649, Skeat 557, D 74)

short lacuna, fol. $135 \mathrm{v}$ (934-936, Skeat 783-785, D 105)

fourth $\mathrm{O}$ fragment, fol. 30

(59) (717-773, Skeat 611-655, D 81-87) third G fragment, fol. 6 (919-960, Skeat 770-806, D 103-108) 


\section{Appendix B: Scribal Stints in Cotton Julius E.vii}

1. Scribe A: fols. $3 r-107 v / 15$ (out of 32 ruled lines): Latin and Old English prefaces, table of contents and 26 homiletic texts/saints' lives (according to Skeat's numbering), ending with Saint Apollonaris.

2. Scribe B: fols. 107v/16-116v: Seven Sleepers, lines 1-426 (Skeat 1-468, D 1-69).

3. 'Scribe C': fols. $117 \mathrm{r}$ (new quire [16], with text continuing on directly from 116v in mid-sentence)-136r: Seven Sleepers, lines 426-772 (Skeat 468-840, D 69-122) (end of text), and all of Mary of Egypt; half of 136r and all of 136v are blank.

4. Scribe A: fols. $137 \mathrm{r}$ (new quire [19])-240v (end of manuscript): 18 homiletic texts/saints' lives, beginning with Abdon and Sennes and ending with $D e$ falsiis diis (ending imperfect).

\section{Works Cited}

Bussières, Michèle. 2004. "Etude d'un recueil hagiographique en vieil anglais, MS British Library Cotton Julius E. vii”. Unpubl. PhD dissertation, University of Poitiers.

Bussières, Michèle. 2007. "The Controversy about Scribe C in British Library, Cotton MSS, Julius E.vii”. Leeds Studies in English 38: 53-72.

Cantara, Linda. 2011. "Saint Mary of Egypt in British Library, MS Cotton Otho B.x". In: Robin Norris (ed.). Anonymous Interpolations in AElfric's Lives of Saints. Old English Newsletter Subsidia 35. Kalamazoo, MI: Medieval Institute Publications, Western Michigan University. 29-69.

$\mathrm{CM}=$ Clayton, Mary and Juliet Mullins (eds. and trans.). 2019. Old English Lives of Saints: Alfric. Dumbarton Oaks Medieval Library 58-60. Cambridge, MA: Harvard University Press.

Corona, Gabriella (ed. and trans.). 2006. Alfric's Life of Saint Basil the Great: Background and Context. Cambridge: Brewer.

$D O E=$ Dictionary of Old English in Electronic Form, A-I. 2018. Ed. Antonette diPaolo Healey et al. Toronto: University of Toronto. 〈http://www.doe.utoronto.ca〉.

Earle, John (ed. and trans.). 1861. Gloucester Fragments: Legends of St Swiðhun and Sancta Maria Agyptiaca. London: Longman, Green, Longman and Roberts.

Gneuss, Helmut. 1972. "The Origin of Standard Old English and Æthelwold's School at Winchester”. Anglo-Saxon England 1: 63-83.

Gretsch, Mechthild. 2003. "In Search of Standard Old English”. In: Lucia Kornexl and Ursula Lenker (eds.). Bookmarks from the Past: Studies in Early English Language and Literature in Honour of Helmut Gneuss. Frankfurt a.M.: Lang. 33-67.

Ker, N. R. 1957. Catalogue of Manuscripts Containing Anglo-Saxon. Oxford: Clarendon.

Kramer, Johanna, Hugh Magennis and Robin Norris (eds. and trans.). 2020. Anonymous Old English Lives of Saints. Cambridge, MA: Harvard University Press. 
Magennis, Hugh (ed.). 1994. The Anonymous Old English Legend of the Seven Sleepers. Durham: Durham Medieval Texts.

Magennis, Hugh (ed. and trans.). 2002. The Old English Life of Saint Mary of Egypt: An Edition of the Old English Text with Modern English Parallel Translation. Exeter: University of Exeter Press.

Magennis, Hugh. 2020. "Synonyms and Lexical Substitutions in Texts of the Old English Life of Saint Mary of Egypt”. English Studies 101: 802-814.

Needham, Geoffrey. 1958. “Additions and Alterations in Cotton MS. Julius E vii”. The Review of English Studies 9: 160-164.

Roberts, Jane. 1986. “The Old English Prose Translation of Felix’s Vita sancti Guthlaci”. In: Paul E. Szarmach (ed.). Studies in Earlier Old English Prose. Albany, NY: State University of New York Press. 363-379.

Scragg, Donald G. 1970. “Initial $h$ in Old English”. Anglia 88: 165-196.

Scragg, Donald G. 1996. “The Corpus of Anonymous Lives and Their Manuscript Context”. In: Paul E. Szarmach (ed.). Holy Men and Holy Women: Old English Prose Saints' Lives and Their Contexts. Albany, NY: State University of New York Press. 209-230.

Skeat, Walter W. (ed. and trans.). 1881-1900, reprinted as 2 vols. 1966. Alfric's Lives of Saints. EETS, OS 76, 82, 94 and 114. London: Oxford University Press.

Torkar, Roland. 1971. "Zu den Vorlagen der ae. Handschrift Cotton Julius E. vii”. Neuphilologische Mitteilungen 72: 711-715.

Upchurch, Robert K. (ed. and trans.). 2007. AElfric's Lives of the Virgin Spouses. Exeter: University of Exeter Press.

Wanley, Humphrey. 1705. Antiquæ literaturæ septentrionalis liber alter, seu Librorum veterum septentrionalium [...] catalogus. Oxford: Sheldonian Theatre. 